\title{
ARTICLE
}

\section{Hannah Arendt and Marxist Theories of Totalitarianism}

\author{
Nicholas Devlin* (D) \\ Robinson College, University of Cambridge \\ ${ }^{*}$ Corresponding author. E-mail: Nd430@cam.ac.uk
}

(Received 28 April 2020; revised 15 July 2020; accepted 16 September 2021)

This article offers a new reading of the place of Hannah Arendt's The Origins of Totalitarianism in the history of totalitarianism theory. Building on a novel genealogy of Marxist theories of totalitarianism, the article traces this inheritance into Arendt's early work on the subject, demonstrating that her "languages" (in the Pocockian sense) were basically continuous with those of interwar Marxism. The article proceeds in three stages. First, it reconstructs two core languages of interwar Marxism (imperialism and Bonapartism). Second, it shows how these languages underpinned a central controversy in Marxist theories of totalitarianism during World War II, a debate conducted in the languages of imperialism and Bonapartism and turning on the relationship between the political and the economic. Third, it shows that Arendt wrote in these languages and contributed to the same debate. In conclusion, this striking affinity with Marxism in Arendt's early work is contrasted with the emergence of classical totalitarianism theory-a project with which Arendt was soon eager to associate herself and which makes a unified and consistent reading of The Origins of Totalitarianism so difficult.

Totalitarianism theory was a central conceptual innovation of the twentieth century, animating Cold War intellectual life and informing foreign-policy decisions across the Western world. It was, therefore, at the center of bitter controversies and polemics over its utility, particularly regarding the appropriateness of comparisons between Nazism and Communism. Histories of the concept have long attempted to disentangle the threads and have emphasized the diverse currents and plural origins of totalitarianism theory in the 1920s and 1930s, ranging from Catholic reactionaries to dissident Marxists. ${ }^{1}$

Relating these stories to the stark binaries of Cold War thought has been more complicated, and the result has sometimes been a breaking down of the history into

\footnotetext{
${ }^{1}$ Abbott Gleason, Totalitarianism: The Inner History of the Cold War (New York and Oxford, 1995); Wolfgang Wippermann, Totalitarismustheorien: Die Entwicklung der Diskussion von den Anfängen bis Heute (Darmstadt, 1998); William David Jones, The Lost Debate: German Socialist Intellectuals and Totalitarianism (Urbana, 1999); Bernard Bruneteau, "Interpréter le totalitarisme dans les années 1930," in Philippe de Lara, ed., Naissances du Totalitarisme (Paris, 2011), 215-52; James Chappel, "The Catholic Origins of Totalitarianism Theory in Interwar Europe," Modern Intellectual History 8/3 (2011), 561-90.

(c) The Author(s), 2021. Published by Cambridge University Press. This is an Open Access article, distributed under the terms of the Creative Commons Attribution licence (https://creativecommons.org/licenses/by/4.0/), which permits unrestricted re-use, distribution, and reproduction in any medium, provided the original work is properly cited.
} 
discrete "moments" of antitotalitarian dissidence. ${ }^{2}$ At the heart of this puzzle is Hannah Arendt and The Origins of Totalitarianism. ${ }^{3}$ Variously understood as a central work of Cold War totalitarianism theory, a triumph of "left" antitotalitarianism and a philosophical masterpiece in a league of its own, the book does not appear to have a neat place in the history. ${ }^{4}$ What further complicates the matter is that the book itself is notoriously hard to pin down: Arendt called it Origins but, famously, explicitly disavowed the idea that it was about origins at all. ${ }^{5}$ Furthermore, its three parts stand in complex if not awkward relation to one another. The first part-"Antisemitism"-combines intellectual, political and social histories of anti-Semitism with an extended discussion of the Dreyfus affair in the French Third Republic. The second part- "Imperialism"-likewise offers intellectual and social histories of "race thinking" and racism, alongside an account of the "boomerang" effects of racism, which undermined civic solidarity, and of the brutal bureaucratic instruments of rule that accompanied the boundlessly ambitious project of imperialist conquest. The third part turns to "Totalitarianism" itself, with dark reflections on the achievement of total domination in the concentration camp, the ever-shifting terrain of the party-state and its secret police, and the senselessness of totalitarian terror. The book's methodology is opaque and its arguments extraordinary in scope. Where exactly does such a singular book sit in the plural and unruly history of totalitarianism theory?

Precisely because the book is so rich and complex, there can be no straightforward and definitive answer to this question. But by setting its argument in a genealogy with deep roots in the interwar period, this article shows just how much Arendt's early work on totalitarianism, including the first two parts of Origins, owes to the Marxist tradition of thinking totalitarianism. This same exercise, though, also shows that the same cannot be said of the third part of the book, nor of the revisions to the text in the second edition. These revisions, it is shown in the conclusion, should be read alongside Carl J. Friedrich and Zbigniew Brzezinski's Totalitarian Dictatorship and Autocracy as a constitutive text of the Cold War moment in totalitarianism theory. ${ }^{6}$

The first two sections of this article set out a reading of Marxist theories of totalitarianism in terms of two "languages" of interwar Marxism. "Languages" is used here in the sense of J. G. A. Pocock's "sub-languages: idioms, rhetorics, ways of talking about politics, distinguishable language-games of which each may have its own

\footnotetext{
${ }^{2}$ Anson Rabinbach, "Moments of Totalitarianism," History and Theory 45/1 (2006), 72-100.

${ }^{3}$ Relevant to this article are the first two editions of this book. To distinguish them clearly, the British title of the first edition is used when referring to the first edition: Hannah Arendt, The Burden of Our Time (London, 1951). For the second edition see Arendt, The Origins of Totalitarianism, 2nd enlarged edn (London, 1958). These are referenced respectively as Burden and Origins hereafter. In-text, the book's title is abbreviated to Origins regardless of edition, which is specified where necessary.

${ }^{4}$ See respectively e.g. Ian Kershaw, To Hell and Back (London, 2015), 458; Enzo Traverso, "Introduction. Le totalitarisme: Jalons pour l'histoire d'un débat," in Enzo Traverso, ed., Le totalitarisme: Le XXe siècle en debat (Paris, 2001), 9-110, at 64-6; Jeffrey C. Isaac, "Critics of Totalitarianism," in Terence Ball and Richard Bellamy, eds., The Cambridge History of Twentieth-Century Political Thought (Cambridge, 2003), 181-201, at 190 .

${ }^{5}$ Hannah Arendt, "[The Origins of Totalitarianism]: A Reply," Review of Politics 15/1 (1953), 76-84, at 78.

${ }^{6}$ Carl J. Friedrich and Zbigniew Brzezinski, Totalitarian Dictatorship and Autocracy (Cambridge, MA, 1956). Hereafter TDA.
} 
vocabulary, rules, preconditions and implications, tone and style."7 This approach is suited to the complex and contested terrain of totalitarianism theories because it presupposes that an "indefinite number of these [political-theoretical] languages may be ... found within a single monoglot text." ${ }^{\text {8 }}$ And Marxism, in particular, can usefully be compared with "a neo-Latin culture in which discourse was the preserve of established clerisies operating stable and continuous languages." If the languages of Marxism were much more widely spoken, and not quite so learned, they were at least constrained by a shared frame of reference and canon of texts, with which all Marxist writers would have (or would pretend to have) some knowledge. The rich allusion to genre, the plagiarism of particular arguments, and a peculiar vocabulary combined to shape Marxism as a space of argument in the early twentieth century. For all that it was characterized by fractious splits and bitter political disagreements, this space of argument had a remarkable degree of unity and consistency. Diverse currents wrote in the same languages.

Two languages in particular provided the bread and butter of Marxist theories of totalitarianism: languages of imperialism and of Bonapartism. The first section of this article establishes the grammar and core vocabulary of these languages, which had roots in the classics of the Marxist canon and a widespread set of assumptions about the nature of twentieth-century capitalism. The work of Otto Bauer is offered here as typical in the way it synthesized these languages in a theory of fascism. The second section shows that these languages were also central to some of the first fully fledged theories of totalitarianism, such as those of Franz Borkenau and James Burnham, whom this article characterizes as anticommunist Marxists. The second section also shows that these arguments, precisely because they were written in Marxist terms, excited a strong reaction from less heterodox figures, such as Franz Neumann, who engaged them on this terrain in the debate about "the primacy of the political," or the relationship between the political and economic spheres more broadly. Overall, the first two sections contribute to the historiography of Marxism by offering a clearer picture of what exactly was lost in what William David Jones called "the lost debate" - the sustained interwar attempt by dissident Marxists to theorize the new "totalitarian" states in Russia, Germany and Italy, which Jones's work unearthed after its burial beneath Cold War polemic. ${ }^{10}$

In the third section, the article shows that Arendt's earlier work on totalitarianism, up to the first edition of Origins, can be read in the same genealogy. It used the same languages (imperialism, Bonapartism) and contributed to the same debate (political versus economic spheres). The third section highlights striking affinities between Arendt's work in this period and the work of classical Marxists of the Second International, such as Rosa Luxemburg, as well as with figures in the genealogy constructed in the article. These affinities suggest that this early work is, indeed, best read as a contributing to these earlier debates about the nature of

\footnotetext{
${ }^{7}$ J. G. A. Pocock, "The Concept of a Language and the Métier d'historien: Some Considerations on Practice," in Pocock, Political Thought and History: Essays on Theory and Method (Cambridge, 2009), $87-105$, at 89.

${ }^{8}$ Ibid., 89.

${ }^{9}$ J. G. A. Pocock, "Quentin Skinner: The History of Politics and the Politics of History," Common Knowledge 10/3 (2004), 532-50, at 549.

${ }^{10}$ See note 1.
} 
totalitarianism. With this established, one can see in sharper relief how Arendt's subsequent work on totalitarianism theory (above all the essay on "Ideology and Terror"), broke from this heritage and contributed to a distinctive Cold War theory of totalitarianism. This second conception had "ideology" at its center and shared its basic assumptions with the work of Friedrich and Brzezinski. In the conclusion, this transition is styled as the emergence of "classical totalitarianism theory." But although this was a break of sorts, it was not a clean break, because the sophisticated and widely propagated nature of Marxist theories of totalitarianism forced Cold War thinkers into a certain openness to and exchange with them.

In sum, this article's contribution works on three fronts. First, the genealogy offers a new reading of the nature of Marxist accounts of totalitarianism before 1945. Second, the article shows that there are substantial conceptual links between these Marxist accounts and Arendt's early work on totalitarianism. And finally, the article develops a sharper sense of what made subsequent totalitarianism theory distinct, including Arendt's own work on the topic later in the 1950s.

\section{Languages and narratives of interwar Marxism}

In interwar Marxist theories of fascism and totalitarianism, the languages of imperialism and Bonapartism stand out as providing recurring tropes and core vocabulary, underpinning a range of arguments at the heart of numerous intra-Marxist conversations in the interwar period. This section establishes the theoretical background to the languages of imperialism and Bonapartism and their role as a key context for Marxist theorizing. It also introduces a typical case of their use in the work of Otto Bauer. In other words, the section sets out the grammar and vocabulary of these languages in archetypal form; subsequent sections show the debates conducted within them, and Arendt's own use of them.

Marx and Engels bequeathed a vast corpus of writing and the literature they inspired is vaster still. In light of this, no definition of Marxism could possibly apply to all intents and purposes. I proceed, instead, with a contextualist account of two "languages" often spoken by professed Marxists in the interwar period which, however, as shown below, had careers that exceeded this ideological and temporal context. Specifically, these are the languages of imperialism and Bonapartism. These languages were not by any means exhaustive of the range of interwar Marxist idioms. Nevertheless, they formed an important part of the Marxist research agenda and can be found in a wide range of texts in the period. In use, languages of imperialism and Bonapartism were often intertwined, but distinguishing their characteristic vocabularies and distinct histories clarifies their connections. For the purposes of this genealogy, imperialism was a narrative about monopoly, and Bonapartism turned on tropes about a declassed mob. Together, they underpinned countless accounts of fascism, the crisis of liberalism and the collapse of Weimar democracy. ${ }^{11}$

\footnotetext{
${ }^{11}$ Ernest Mandel, "Introduction," in Leon Trotsky, The Struggle against Fascism in Germany (Harmondsworth, 1975), ix-liii, at xxiii-xxxii, for an overview of perspectives beyond Trotsky's, albeit with a Trotskyist slant. See also Ian Kershaw, The Nazi Dictatorship: Problems and Perspectives of Interpretation (London, 1985), 24-6.
} 
Theories of imperialism were especially central to interwar Marxist thinking. Contrary to its image of dull determinism, the mainstream of Marxism in the early twentieth century was not, as one recent contribution would have it, "a set of inflexible and inviolate historical-economic laws, requiring and admitting no modification or addition." 12 On the contrary, it was a staple of Marxism at this time that capitalism had entered a new imperialist phase, distinct from the age of free trade with which Marx had been concerned. ${ }^{13}$ Before World War I, Rudolf Hilferding's Finance Capital was considered a crowning achievement not just of this discourse, but of Marxism since Marx's death. Otto Bauer, one of the leading lights of the Austrian Socialist Party, hailed the book as "like a fourth volume of Capital," a judgment with which Karl Kautsky concurred. ${ }^{14}$ During the war itself, many of the book's arguments were popularized by Lenin in his book on imperialism. For one commentator, the transformation of Marxism implied in these works was "part of a revolution as dramatic as ... the marginalist revolution in bourgeois economics." ${ }^{15}$ In any case, with an impeccable pedigree in socialdemocratic and communist canons, the language of imperialism straddled the Marxist sectarian divide long into the interwar period.

For both Hilferding and Lenin, "finance capital" was not really about the power of the banks, but about the increasing concentration of industry and economies of scale, and the kind of relationship these developments fostered between production and profit. ${ }^{16}$ The capital sums needed to compete under these conditions were so large that only a small number of big banks could supply them. These banks, in turn, wanted to rationalize their balance sheets and discourage unnecessary competition between their debtors. The initiative of the entrepreneur was therefore ever further constrained by the demands of financial bureaucracies. On Lenin's reading, this was a process engendering ever more concentrated, rationalized and monopolistic production:

It is characteristic of capitalism in general that the ownership of capital is separated from the application of capital to production, that money capital is separated from industrial or productive capital, and that the rentier, who lives entirely on income obtained from money capital, is separated from the entrepreneur and from all who are directly concerned in the management of capital. Imperialism, or the domination of finance capital, is that highest stage of capitalism in which this separation reaches vast proportions. ${ }^{17}$

\footnotetext{
${ }^{12}$ Max Pensky, "Western Marxism," in Peter E. Gordon and Warren Breckman, eds., The Cambridge History of Modern European Thought, online, vol. 2 (Cambridge, 2019), 258-88, at 263, https://doi.org/ 10.1017/9781316160879.

${ }^{13}$ Richard B. Day and Daniel Gaido, eds., Discovering Imperialism: Social Democracy to World War I (Leiden and Boston, 2012).

${ }^{14}$ Cited in J. E. King, "Hilferding's Finance Capital in the Development of Marxist Thought," History of Economics Review 52/1 (2010), 52-62, at 52.

${ }^{15}$ Lawrence Birken, "Lenin's Revolution in Time, Space and Economics and Its Implications: An Analysis of Imperialism," History of Political Economy 23/4 (1991), 613-23, at 613.

${ }^{16}$ Laurence Harris, "Finance Capital," in Tom Bottomore, ed., A Dictionary of Marxist Thought, 2nd revised edn (Oxford, 1991), 198-203.

${ }^{17}$ Vladimir Il'ich Lenin, Imperialism: The Highest Stage of Capitalism: A Popular Outline (London, 2010), 70-71. Translator not given.
} 
Insofar as this was the basic argument, Lenin's theory did not diverge much from Hilferding's. ${ }^{18}$ The result of these trends was massive cartels operating monopolies across every stage of production. Imperialism followed from these conditions, since uncompetitive conditions at home led to an excess of capital seeking investment overseas, and because such massive economies of scale required massive, captive markets to match.

Imperialism was thus a theory of monopoly and vice versa, and this theory underpinned a comprehensive analysis of world capitalism which built upon, but differed from, what was understood of Marx's Capital. Its core was that the age of free trade and competition between entrepreneurs had been superseded by an age of technologically conditioned planned production, undertaken by monopolies spanning several industries and managed by financial bureaucracies. One can give an account of interwar Marxism that stresses the theoretical divisions that widened between social democrats and communists after $1918 .{ }^{19}$ But this should not obscure the significant agreement that united them as two wings in the same tradition, speaking similar languages. ${ }^{20}$

That fascism was a distinct, populist form of reactionary politics-ultimately, in a sense, a democratic one-led Marxists to draw on another aspect of their theoretical heritage: Marx's analysis of Bonapartism in The Eighteenth Brumaire of Louis Bonaparte. In this essay, Marx offered a history of the French Second Republic culminating in the coup d'état which brought Napoleon III to power. The essay's reception has as broad and complex a history as any of Marx's writings. ${ }^{21}$ For the New Left, Bonapartism signified above all an instance of the "relative autonomy" of the state from particular class interests, and it is probably in this form that twenty-first-century readers will have encountered the concept. ${ }^{22}$ But Bonapartism long played an important role in theorizing fascism-both in the interwar period itself, and in postwar historiographical debates. ${ }^{23}$ Scholarly accounts have often emphasized the otherwise obscure opposition communist August Thalheimer as the archetypal Marxist theorist of fascism-as-Bonapartism. ${ }^{24}$ For Thalheimer, there were three essential features of a Bonapartist situation: a bourgeoisie cowed into relinquishing direct rule in order to protect its economic interests, the presence of small

\footnotetext{
${ }^{18}$ For how their accounts did differ, see Leszek Kołakowski, Main Currents of Marxism, trans. P. S. Falla, vol. 2, The Golden Age (Oxford, 1978), 303.

${ }^{19}$ David Beetham, "Introduction," in Beetham, ed., Marxists in the Face of Fascism: Writings by Marxists on Fascism from the Inter-war Period (Manchester, 1984), 40-42.

${ }^{20}$ Jukka Gronow, On the Formation of Marxism: Karl Kautsky's Theory of Capitalism, the Marxism of the Second International and Karl Marx's Critique of Political Economy, On the Formation of Marxism, ebook (Leiden and Boston, 2016), 3-4.

${ }^{21}$ Donald Reid, “Inciting Readings and Reading Cites: Visits to Marx's The Eighteenth Brumaire of Louis Bonaparte," Modern Intellectual History 4/3 (2007), 545-70.

${ }^{22}$ Ralph Miliband, "Bonapartism," in Bottomore, A Dictionary of Marxist Thought, 55-6.

${ }^{23}$ For a fuller treatment see Jost Dülffer, "Bonapartism, Fascism and National Socialism," Journal of Contemporary History 11/4 (1976), 109-28.

${ }^{24}$ Mandel, "Introduction," xxx; Dülffer, "Bonapartism, Fascism and National Socialism," 111-12; Kershaw, The Nazi Dictatorship, 24-6.
} 
farmers and peasants who are unable to express their class interest in a collective way, and a proletariat that has just experienced a major defeat. ${ }^{25}$

But Thalheimer's was just one way in which analogies could be drawn between Marx's narrative in The Eighteenth Brumaire and the rise of fascism. For many other Marxist writers, the most direct lesson to be drawn from the Bonapartism story was Marx's sketch of the social composition of the Bonapartist movement and Napoleon III's electoral base. In his essay, Marx had sketched a vivid portrait of the Society of 10 December-ostensibly a charitable organization that actually served as a front for Napoleon III's political ambitions. Marx described the society as a paramilitary force made up of "degenerate wastrels on the take, vagabonds, demobbed soldiers, discharged convicts"-and so on in colorful prose. Crucially, Marx summarized Napoleon III's movement as formed of "the dregs, refuse and scum of all classes". ${ }^{26}$ This trope, indeed the precise vocabulary, is to be found throughout the genealogy traced in this article. For interwar Marxists drawing on this tradition, fascism was understood as the movement of the declassed mob, dangerous precisely because it had no class interest.

Otto Bauer is a good example of how the languages of imperialism and Bonapartism were typically brought together. Arendt was familiar with at least some of his work, and therefore it has a special claim to relevance for the purposes of this genealogy, within the enormous range of potential examples. But it is also representative of the kind of argument that was made in these Marxist languages. In 1936, Bauer described how the joint crises of capitalism and bourgeois democracy had allowed the fascist movement to expand from its beginnings as a movement of disaffected veterans and intellectuals into an overwhelming mass movement. Eventually, "The fascist militia became the rallying point of the declassed of all classes." ${ }^{27}$ But this account of the social composition of the fascist movement was tied to a deeper analysis of capitalist imperialism, which drew on Hilferding explicitly. As one scholar summarizes his argument, "the general conditions of the rise of fascism lay ... in the evolution of capitalism in its imperialist tendencies. In the last quarter of the nineteenth century, the liberal phase of capitalism had been superseded by monopolist concentration of capital, increasing organization of social forces and protectionism." 28 The incompatibility of these trends with liberal-democratic legal norms and free trade underpinned a chronic economic dysfunction, a crisis that ran much deeper than the Great Depression. It was this, and the destruction of the Great War, that unleashed an unstable coalition of veterans and the declassed against an apparently broken democracy. ${ }^{29}$ Bauer combined an account of the role of criminal and desperate elements in fascist street violence and the suppression of trade unions with a deeper story of the

\footnotetext{
${ }^{25}$ August Thalheimer, "Über den Faschismus" (1930), in Thalheimer, Der Faschismus in Deutschland (Frankfurt am Main, 1973), 28-46, at 29-31.

${ }^{26}$ Karl Marx, "The Eighteenth Brumaire of Louis Bonaparte," in Marx, Later Political Writings, ed. Terrell Carver (Cambridge, 1996), 31-127, at 78.

${ }^{27}$ Otto Bauer, Zwischen zwei Weltkriegen? Die Krise der Weltwirtschaft, der Demokratie und des Sozialismus (Prague, 1936), 122-3, my emphasis.

${ }^{28}$ Gerhard Botz, "The Austro-Marxist Interpretation of Fascism," Journal of Contemporary History 11/4 (1976), 129-56, at 142.

${ }^{29}$ See the extract Otto Bauer, "Fascism," in Beetham, Marxists in the Face of Fascism, 294-7.
} 
transformation of capitalism, linking both to national chauvinism and economic centralization. This mob was supported by the bourgeoisie, but soon (temporarily) ran out of its control in the depth of the crisis. ${ }^{30}$ Such was the fate of Continental democracy in the face of the crises unleashed by imperialism: monopoly, world war, extreme social dislocation.

Bauer dubbed the result "bureaucratically directed monopoly capitalism," since the dysfunctions of the emergency measures excited by the Great Depression worsened the underlying problems and drew the state into an ever closer deathly embrace with monopoly and stagnation. ${ }^{31}$ What Bauer's work also shows, then, is the way in which the fascism story became one of state intrusion into, and regulation of, the economy. In the face of the collapse of international trade and credit, restrictions on imports were necessary; without export markets, supply for some goods was left to flood the home market, so price controls became irresistible; state-directed cartelization appeared to be another way out, but this deepened the relationship between private financial bureaucracies and those of the state. ${ }^{32}$ For Bauer, the crucial difference between this process of rationalization and socialism was that the dysfunctional hybrid of "bureaucratically directed monopoly capitalism" had been constructed "planlessly under the pressure ... of the crisis," and was underpinned by destructive international competition which encouraged militarism. ${ }^{33}$ Above all, it could not be compared to socialism because it "does not abolish that concentrated capitalist private property in the means of production, rather [it] serves their interests." ${ }^{\text {}}$

\section{From fascism to totalitarianism: anticommunist Marxism and "the primacy of the political"}

An important strand in Bauer's work, then, had been to narrate the rise of fascism in terms of two discourses: the theory of imperialist monopoly capitalism on the one hand, and accounts of fascist social movements in terms of Bonapartism on the other. In use, the distinction was not so neat, since the coalition of the declassed unleashed by fascism was itself a product of monopoly and the economic crisis of world war, both understood as products of imperialism. The result was the state trying to hold the crumbling economic system together in a dynamic that dragged it ever closer to war. Bauer was aware that this picture of state intervention might have a superficial resemblance to socialist planning-asking rhetorically, "doesn't [fascism] subordinate all economic forces to the will of the state, therefore all 'selfinterest' to the 'common interest'?" 35 - but he was keen to contest this implication, insisting, "Planned economy ... is impossible on the basis of capitalist private property." ${ }^{\prime 36}$ The inevitability of socialism as a rational, internationalist order therefore underpinned Bauer's basic assumptions about the nature of fascism.

\footnotetext{
${ }^{30}$ Bauer, Zwischen zwei Weltkriegen?, 123.

${ }^{31}$ Ibid., 76.

${ }^{32}$ Ibid., 66-70.

${ }^{33}$ Ibid., 73, 78-9.

${ }^{34}$ Ibid., 78.

${ }^{35}$ Ibid., 78, alluding to the Nazi slogan "Gemeinnutz geht vor Eigennutz," or "the common interest before self-interest."

${ }^{36}$ Bauer, Zwischen zwei Weltkriegen?, 77.
} 
Over the course of the 1930s, and especially catalyzed by the Nazi-Soviet pact of 1939, Marxist languages were used explicitly to contest this belief in the inevitability of socialism. This move was characteristic of ex-communists, as they developed from a perspective that was anticommunist in the narrow, party-political sense towards a comprehensive anticommunism in a political-theoretical sense. This move was at the heart of the first Marxist theories of totalitarianism, as in the work of Franz Borkenau or James Burnham. Both abandoned their faith in the classless society as the inevitable, transcendental resolution to the dialectic of class struggle but kept important elements of their theoretical commitments and historical narratives. This included, in particular, their understanding of capitalism's historical development and interwar crisis, and of fascism as the product of the latter, all of which was expounded in terms of the languages of Marxism traced in this genealogy.

These arguments were heretical—indeed, scandalous - from certain Marxist perspectives, particularly when they turned to the question of the relationship between the political and the economic, but this should not obscure the fact that they were written in Marxist languages. Indeed, that is probably why they were so urgently addressed by Franz Neumann in Behemoth. The following section of this article proceeds through these examples-Borkenau, Burnham and Neumann-because of provable links with the works of subsequent totalitarianism theory, including Arendt's work. But in its own right, this section offers a new reading of the nature of Marxist theories of totalitarianism and the debates they excited.

Franz Borkenau was a typical anticommunist Marxist. He had been a student communist leader and then a researcher for the Communist International, but left the party in 1929 and was subsequently to be found on the margins of the Frankfurt school. ${ }^{37}$ In the second half of the 1930s, which he spent in exile in Great Britain, he wrote a remarkable series of books on Nazism, communism and totalitarianism. Underpinning it all was a revisionist Marxist methodology: "Marx was right in his analysis of the trend and development of capitalism ... But he was essentially wrong in his belief that contradictions in the social body are always overcome by some 'Synthesis' radically solving them." ${ }^{38}$ Capitalism's contradictions did constitute its law of movement, but this movement was not necessarily progressive. This argument, though politically subversive, was written in the languages of interwar Marxism. For Borkenau, capitalism's "trend and development" were characterized by the demise of free trade as a viable settlement for world capitalism. In the twentieth century, economic and social success was "determined overwhelmingly by technical equipment due to former generations, and to the general economic conditions of different countries competing with one another."39 An integrated world market demanded agricultural "competition" between Germany and Argentina, or industrial competition between the United States and Italy-the result was an impossible settlement in which the national

\footnotetext{
${ }^{37}$ For a biographical sketch see Richard Löwenthal, "Preface," in Franz Borkenau, End and Beginning, ed. Richard Löwenthal (New York, 1981), vi-ix. A more comprehensive intellectual biography is available in German. See Birgit Lange-Enzmann, Franz Borkenau als politischer Denker (Berlin, 1996).

${ }^{38}$ Franz Borkenau, Pareto (New York, 1936), 203.

${ }^{39}$ Ibid., 199.
} 
political architecture did not reflect the international scale of economic activity and organization. ${ }^{40} \mathrm{He}$ viewed the whole interwar period as the history of this contradiction deepening in a vicious cycle in which each political reaction worsened the economic conjuncture, which in its turn exerted yet more strain on the political system. This account of the crisis of liberalism in terms of dysfunctional competition would lead him to conclude "that the totalitarian revolution is so deeply rooted in the whole trend of development of our modern society ... Some of its results imposed themselves on modern society almost by a sort of technical necessity." ${ }^{\prime 1}$ Borkenau's narrative has clear parallels with that of Bauer's discussed above, particularly the conception of a breakdown of competition in the face of economies of scale.

This theoretical lens shaped Borkenau's narrative of Weimar's collapse, which likewise shared its basic contours with Marxist accounts of the crisis of liberalism and the rise of fascism. After 1918, he argued, nothing much had changed in the real constitution of Germany: the same imperial army and bureaucracy remained in control. ${ }^{42}$ The party system was dysfunctional, serving only to assemble coalitions of special interests, a charge he levelled especially at the German Social Democratic Party, which he characterized alongside other Continental socialist parties as a vehicle for "protecting the interests of their members within the frame of the capitalist system, without seriously attempting to change anything of it." ${ }^{43}$ But meanwhile the country was battered by enormous political and economic crises, including widespread hunger and the proletarianization of the middle classes. There was economic and social change, which strained to find a political expression, but no constitutional change to reflect this new reality: "Every economic status, every political and moral value, had been revolutionized in the meantime. But the party system remained unchanged and in a state of deadlock." ${ }^{44}$ The Nazi movement, which "drew its recruits from the discomfited and despairing of all classes," was the extra-constitutional explosion of this new social and economic reality. ${ }^{45}$ Throughout Borkenau's work in the late 1930s, there was a liberal inflection to the analysis, particularly in his admiration for laissez-faire when it could still work, and the place of Vilfredo Pareto is another idiosyncratic element. ${ }^{46}$ Nevertheless, the primary mode was the Marxist imperialism discourse of the technologically conditioned breakdown of competition and rise of monopoly, with its sister story about the social composition of the fascist movement itself, drawn from Bonapartism theory. ${ }^{47}$

\footnotetext{
${ }^{40}$ See also Franz Borkenau, Socialism, National or International (London, 1942).

${ }^{41}$ Franz Borkenau, "A Program for Counter-revolution," Common Sense 9/12 (1940), 12-15, at 12.

${ }^{42}$ Franz Borkenau, The New German Empire (Harmondsworth, 1939), 19.

${ }^{43}$ Franz Borkenau, "Un essai d'analyse historique: La crise des partis socialistes dans l'Europe contemporaine," Annales d'histoire économique et sociale 7/34 (1935), 337-52, at 345.

${ }^{44}$ Borkenau, New German Empire, 19.

${ }^{45}$ Ibid., 20.

${ }^{46}$ On this see esp. William David Jones, "Toward a Theory of Totalitarianism: Franz Borkenau's Pareto," Journal of the History of Ideas 53/3 (1992), 455-66. Interestingly, James Burnham also drew extensively on Pareto, but pursuing this connection would be beyond the scope of this essay.

${ }^{47}$ Borkenau's account of declassed masses, produced by the degeneration of the free market into a rigid monopolistic economy, was an enduring feature of his totalitarianism theory. He used the "declassed" vocabulary in Franz Borkenau, The Totalitarian Enemy (London, 1940), e.g. 164.
} 
James Burnham's The Managerial Revolution also fits squarely into this discourse. Burnham famously blazed the trail from revolutionary Trotskyism to Cold War conservatism, and although The Managerial Revolution was a step in this direction, it was still very much a product of the Marxist imagination, and particularly its imperialism discourse. His description of capitalism as a distinct mode of human social organization distinguished by "commodity production," "money ... as capital" and its "two special classes" left nothing for Marxists, orthodox or unorthodox, to quibble with. ${ }^{48}$ And, indeed, Burnham admitted that he more or less accepted the Marxist account of capitalist crisis, only rejecting the supposition that socialism must follow:

A survey of the Marxist literature quickly reveals that it is far, far weightier in the analysis of capitalism by which it reaches the conclusion that capitalism will not last ... than in the analysis by which it motivates the all-important positive belief that socialism will replace capitalism. Yet the fullest agreement with the first, and I agree with much of it, does not in any way compel us to accept the second. ${ }^{49}$

Burnham's was also an account of transnational economic actors outgrowing their national political frame - "a large number of sovereign nations ... is incompatible with contemporary economic and social needs"-and of capitalism faced with problems that it could not resolve-especially mass unemployment and the need for infrastructure projects well beyond the means of a single capitalist. ${ }^{50}$ But the heart of the case was the separation of ownership and control of capital. Fundamentally, capitalism was coming to an end, he argued, because "ever greater percentages of the economy are getting wholly or partly out of control by the capitalists and subjection to capitalist relations." ${ }^{51}$ The separation, perhaps, was reaching "vast proportions."

Burnham and Borkenau both grappled with their Marxist heritage and asserted their independence of it. Burnham rejected the standard communist line that fascism was "the extreme end point of 'monopoly-finance-capitalism"' and Borkenau contested what he called "the Hobson-Hilferding-Lenin school of thought on imperialism." N2 Nevertheless, in both cases the disagreement was delimited. Burnham's argument was not so much that the Marxist account of capitalism's crisis was wrong, but rather that it couldn't recognize fascism as a truly postcapitalist social order. Borkenau's point was broader, but still limited to rejecting the arguments that nationalism was merely the result of a corrupt "labour aristocracy" and that imperialism made war inevitable. ${ }^{53}$ Again, that they saw themselves as contesting this discourse, and perhaps Lenin's version of it in particular, is clear

\footnotetext{
${ }^{48}$ James Burnham, The Managerial Revolution or What Is Happening in the World Now (London, 1942), $11,12,16$, original emphasis.

${ }^{49}$ Ibid., 38.

${ }^{50}$ Ibid., 165, 122.

${ }^{51}$ Ibid., 104; cf. Lenin, Imperialism, 70-71.

${ }^{52}$ Burnham, Managerial Revolution, 216; Borkenau, Socialism, National or International, 75-95. For a short example of the Communist line see e.g. Dmitrii Manuilski, "On Fascism," in Beetham, Marxists in the Face of Fascism, 157-61.

${ }^{53}$ Borkenau, Socialism, National or International, 75-94.
} 
in that both of them used the terminology of "superimperialism" or "super-states." 54 In Borkenau's case, this was surely a conscious reference to Lenin's polemical exchange with Karl Kautsky on just this issue. ${ }^{55}$ But conscious or not, the evidence offers ample reason to read Burnham and Borkenau as heretics who continued to carry a great deal of theoretical baggage. Their political-polemical moves notwithstanding, they continued to write in the languages of interwar Marxism.

For Neumann, the implications of this argument were unacceptable, as Jones showed. ${ }^{56}$ Recent literature on Neumann has emphasized Carl Schmitt as a central interlocuter in Behemoth. ${ }^{57}$ But one should not underestimate the centrality of "monopoly capital" to this book. Even more so than Borkenau, though with striking parallels, Neumann's account of the failure of Weimar turned on this point. In short: the Weimar constitution had attempted to construct a pluralistic system of power sharing between different social groups; it was forged in a moment of unique strength for the labor movement, but this balance of power soon changed and, eventually, the real social equilibrium broke out of its Weimar frame. Weimar "failed because it did not see that the central problem was the imperialism of German monopoly capital ... The more monopoly grew, the more incompatible it became with the political democracy." 58 Monopoly-as-imperialism was "the monster that lay within the German economic system" and, without defeating it, Weimar was doomed. ${ }^{59}$ Fascism-as-Bonapartism had its influence here too, such as when Neumann described the Nazi Party as "composed of the most diverse social strata but never hesitating to take in the dregs of every section." 60 For Neumann, of course, this heritage was not baggage, but a point of pride. Indeed, the whole point of the discussion of the Nazi economy was to show that "the antagonisms of capitalism are operating on a higher and, therefore, more dangerous level." ${ }^{61}$ He repeated this point throughout the book, using it to frame the discussion, as in: "it is the profit motive that holds the machinery together" and " $[\mathrm{t}]$ he conflicts are reproduced on a higher level and the incentives of competition remain operative." 62

The reason Neumann stressed this point so urgently was that he thought that the likes of Burnham had brought the whole premise of Marxism into question. ${ }^{63}$ As other literature has shown, an important context here was the Frankfurt school debate over "the primacy of the political." 64 Particularly important was Friedrich

\footnotetext{
${ }^{54}$ Respectively ibid., 172; Burnham, Managerial Revolution, 167-74.

55"Somebody might say it is not only imperialism, but superimperialism ... It is a quarrel about words." Borkenau, Socialism, National or International, 172; Cf. Lenin, Imperialism, esp. Ch. 9.

${ }^{56}$ Jones, The Lost Debate, 139-41.

${ }^{57}$ See esp. Keith Tribe, Strategies of Economic Order: German Economic Discourse, 1750-1950 (Cambridge, 1995), 169-202; Duncan Kelly, “Rethinking Franz Neumann's Route to Behemoth," History of Political Thought 23/3 (2002), 458-96.

${ }^{58}$ Franz Neumann, Behemoth: The Structure and Practice of National Socialism, 1933-1944 (Chicago, 2009), 14.

${ }^{59}$ Ibid., 185.

${ }^{60}$ Ibid., 33, my emphasis.

${ }^{61}$ Ibid., 227.

${ }^{62}$ Ibid., 354, 291.

${ }^{63}$ Again this point is stressed in Jones, The Lost Debate, 139-41.

${ }^{64}$ Helmut Dubiel and Alfons Söllner, eds., Wirtschaft, Recht und Staat im Nationalsozialismus: Analysen des Instituts für Sozialforschung, 1939-1942 (Frankfurt am Main, 1981), 7-31, esp. 15-19; see also Martin
} 
Pollock's claim that the rise of what he called "state capitalism" "signified the transition from a predominantly economic to an essentially political era," which itself built on the "basic assumption ... that 19th century free trade and free enterprise are on the way out." 65 Ultimately, then, Pollock too claimed that capitalism was being superseded, and that what followed was the replacement of liberal competition with (state) bureaucratic monopoly.

For Neumann, the problem was that if fascism was not a product of, and moved by, capitalist contradictions, then in a sense it was simply "the administration of things," in Engels's utopian sense-the replacement of irrational, inhuman economic laws with rational and conscious control. "The obstacles that such a society meets are exclusively natural, no longer economic ... There is no longer any antagonism between the productive forces and the social conditions of production."66 But if fascism really represented rational, political control of the economy, then that ideal was itself undermined- "it might just as easily be hell." ${ }^{67}$ Neumann positioned himself explicitly against Burnham, Pollock and Bruno Rizzi in this respect. ${ }^{68}$ Helmut Dubiel and Alfons Söllner make the suggestion that in comparison with his Frankfurt school interlocutors, "Neumann's position appears as traditional and orthodox." 69 Ultimately they retreat from this assertion, and offer a reading which synthesizes the two positions. But the disagreement should not be denied. The very point of Neumann's phrase "totalitarian monopoly capitalism" was to stress that it was politically totalitarian but economically monopolistic: "This is the only possible meaning of [the] primacy of politics over economics ... Shall the state become the weapon by which the masses will be made completely subservient to the policies of the industrial empires within it?"70 Nazism's dual nature was a product of its economic contradictions since "in a monopolistic system profits cannot be made and retained without totalitarian political power, and that is the distinctive feature of National Socialism."71 To admit otherwise would be "profoundly pessimistic." 72 Why play the game of emancipatory politics, understood as subordinating unconscious and destructive economic forces to rational political control, if that subordination could in fact be identical with fascism?

Jay, The Dialectical Imagination: A History of the Frankfurt School and the Institute of Social Research, 1923-1950 (Berkeley, Los Angeles and London, 1996), 143-67. Where I depart from Jay is in placing Neumann firmly within the mainstream or "orthodoxy" of Marxism.

${ }^{65}$ Friedrich Pollock, "State Capitalism: Its Possibilities and Limitations," in Andrew Arato and Eike Gebhardt, eds., The Essential Frankfurt School Reader (Oxford, 1978), 71-94, at 78, 72. On this text see Barbara Brick and Moishe Postone, "Introduction. Friedrich Pollock and the 'Primacy of the Political': A Critical Reexamination," International Journal of Politics 6/3 (1976), 3-28.

${ }^{66}$ Neumann, Behemoth, 225.

${ }^{67}$ Ibid., 227.

${ }^{68}$ Ibid., $500 \mathrm{n}$. 1. Rizzi, whose identity was unknown at the time, was another important theorist in this current.

${ }^{69}$ Helmut Dubiel and Alfons Söllner, "Die Nationalsozialismusforschung des Instituts für Sozialforschung: Ihre wissenschaftsgeschichtliche Stellung und ihre gegenwärtige Bedeutung," in Dubiel and Söllner, eds., Wirtschaft, Recht und Staat im Nationalsozialismus: Analysen des Instituts für Sozialforschung, 1939-1942 (Frankfurt am Main, 1981), 7-31, at 18.

${ }^{70}$ Neumann, Behemoth, 260.

${ }^{71}$ Ibid., 354.

${ }^{72}$ Ibid., 227. 
In a sense, though, the debate about "the primacy of the political" was somewhat one-sided. Neumann insisted on the economic laws of imperialist monopoly capitalism as the determining influence on Nazism's development. But Borkenau and Burnham spoke of a fusion of the political and the economic, rather than the overriding power of political imperatives as such. Although Borkenau did suggest that, in Nazi Germany, "Economics were throughout subordinated to politics," he also compared the Nazi economy with "Egypt under the Pharaohs," arguing that it represented "the development of a new type of slavery."73 Burnham, for his part, warned of "a fused political-economic apparatus" by means of which managerial power would be executed: "Control over the instruments of production will be exercised by the managers through their de facto control of the state institutionsthrough the managers themselves occupying the key directing positions in the 'unlimited state." "74 In support of this argument, incidentally, Burnham had cited the English ex-communist Freda Utley, who had spent some years living in the Soviet Union before emigrating to the USA. She also made the comparison to "Egypt under the Pharaohs" and described the whole system as "modern industrial feudalism."75 The image of a feudal fusion, but not necessarily centralization, of political and economic power, is perhaps the heart of the anticommunist Marxist theory of totalitarianism.

In sum, the tradition of thinking fascism and totalitarianism through the languages of imperialism and Bonapartism had, during World War II, been split in a bitter debate over the nature of the political and the economic under totalitarianism and fascism. After the war, Hannah Arendt was to pick up these threads, making an innovative contribution to these older Marxist debates.

\section{The Origins of Totalitarianism and Marxism}

One problem for reconstructing the links between Hannah Arendt's work and Marxism is that Arendt was pointedly not a Marxist. Indeed, it has been argued that Arendt may have "deliberately avoided making reference" to her socialist predecessors in the council communist tradition in On Revolution. Elsewhere her aversion to being associated with Marxism led her to qualify her praise of Rosa Luxemburg's life and work with the claim that Luxemburg shouldn't be considered a Marxist. $^{76}$ These efforts to establish distance clearly worked: in the literature, it is common to dismiss the affinities between Arendt's work and Marxism as superficial, or to overlook them altogether. ${ }^{77}$ For example, a recent article that situates the argument of Origins in two debates-on the (federal) reconstruction of postwar

\footnotetext{
${ }^{73}$ Borkenau, The Totalitarian Enemy, 225, 52.

${ }^{74}$ Burnham, Managerial Revolution, 117.

${ }^{75}$ Freda Utley, The Dream We Lost: Soviet Russia Then and Now (New York, 1940), 125, 145.

${ }^{76}$ James Muldoon, “The Origins of Hannah Arendt's Council System," History of Political Thought 37/4 (2016), 761-89, at 768, 775. The claim about Luxemburg, cited by Muldoon, was made in Arendt's glowing review of J. P. Nettl's biography of Luxemburg. See Hannah Arendt, “Rosa Luxemburg," in Arendt, Men in Dark Times (San Diego, New York and London, 1968), 33-56, at 38.

${ }^{77}$ Roy T. Tsao, “The Three Phases of Arendt's Theory of Totalitarianism," Social Research: An International Quarterly 69/2 (2002), 583; Waseem Yaqoob, "Reconciliation and Violence: Hannah Arendt on Historical Understanding," Modern Intellectual History 11/2 (2014), 385-416, at 390. An
} 
Europe and the international sources of Nazism-hardly considers this major strand of internationalist thought in interwar Europe, which most certainly had much to say on the limits of the nation-state and fascism as a transnational phenomenon. ${ }^{78}$ But there is ample evidence that Arendt was aware of and engaged seriously with Marx and the problems of Marxism in Origins. It has recently been shown, indeed, that engaging with Marxist political economy was a central concern of her work leading up to The Human Condition, which appeared the same year as the revised second edition of Origins (1958). ${ }^{79}$ When the question is posed in terms of the Marxist languages recovered above, it becomes easier to see Arendt's debts to Marxism as well as her departures from it.

The task remains complicated because Origins, in its final form, is really three different theories of totalitarianism in one book. ${ }^{80}$ Sharp changes of focus in the course of the book's drafting, as well as significant revisions between editions, mean that the book does not admit a single, unified reading. As Roy T. Tsao has shown, most of Parts One and Two of Origins were drafted before 1947, and were conceived as part of a book on Nazism alone. It is these parts that deal with anti-Semitism, the Dreyfus affair, racism and imperialism, and they are essentially historical in character. Roughly speaking, these chapters constitute Arendt's first theory of totalitarianism. Part Three of the same first edition was written over the following two years and, argues Tsao, represented an attempt to incorporate the Soviet Union into her thinking. These chapters include Arendt's first account of "Totalitarianism in Power," including terror and the concentration camps, and their theoretical character is perhaps a product of Arendt's belief in the need for a new social science to make sense of totalitarianism. ${ }^{81}$ In any case, Part Three of the first edition offered a second theory of totalitarianism. Finally, the revisions between the first and second editions, undertaken between 1951 and 1956, and especially as represented by the new final chapter, entitled "Ideology and Terror," constitute another theory again. ${ }^{82}$ This "third" theory is discussed in the conclusion. For now, the focus is on the two theories offered in the first edition of Origins, and especially the first.

The "first" theory in Origins, as it was made in Parts One and Two of the first edition of the book, is much richer and more complicated than the quite distinct theory offered in Part Three. At its broadest, it is an account of the swallowing of the political by the social. This resulted partly from the unstable architecture of the nation-state, the most corrosive symptom of which was the rise of political

important exception is Muldoon, “The Origins of Hannah Arendt's Council System." Muldoon highlights especially Heinrich Blücher's influence at 765-70.

${ }^{78}$ William Selinger, "The Politics of Arendtian Historiography: European Federation and The Origins of Totalitarianism," Modern Intellectual History 13/2 (2016), 417-46. The exception is a discussion of Arendt's readings of Otto Bauer and Karl Renner, but this is confined to their writing on the national question.

${ }^{79}$ Mimi Howard, "Hannah Arendt's Contribution to a Critique of Political Economy," New German Critique 47/2 (2020), 45-80.

${ }^{80}$ Tsao, "Three Phases."

${ }^{81}$ Heather and Stolz underline the importance of this aspect of Arendt's thinking. See Gerard P. Heather and Matthew Stolz, "Hannah Arendt and the Problem of Political Theory," Journal of Politics 41/1 (1979), $2-22$.

${ }^{82}$ Tsao, "Three Phases," passim, esp. 579-82; see also Elisabeth Young-Bruehl, For the Love of the World (London, 1982), esp. 181-204, for an account of the circumstances under which Origins was written. 
anti-Semitism. It was also a consequence of "the political emancipation of the bourgeoisie," who went on to impose their own interests and the economic logic of their private lives on the nation-state, the result of which was imperialism and racism as alternatives to nationalism. ${ }^{83}$ The social histories of both anti-Semitism and racism were important elements of this argument. That the nation-state was in trouble with or without imperialism, Arendt thought was clear, and explicitly described the Dreyfus affair as just such a crisis-as anti-Semitism without imperialism. ${ }^{84}$ The origins of totalitarianism were in the combination of these two elements.

The originality of this argument was in Arendt's understanding of the crisis of the nation-state as a crisis of the political itself. The central place of imperialism in the argument, though, bespeaks the serious level of engagement between Arendt and interwar Marxism, and in this part of the argument the continuities are clear. ${ }^{85}$ Languages of Bonapartism and imperialism both played an important role in Arendt's thinking, as did the debate about the primacy of the political. Again as Tsao has noted, her arguments about imperialism were originally intended for a book called Imperialism, some of which was published as articles. ${ }^{86}$ But these pieces contributed to the interwar Marxist debate about the interplay between political and economic spheres, and therefore it would not right to argue, as Tsao does, that Arendt's "concern with capitalism is restricted almost entirely to the ethos of the ruling bourgeoisie" as opposed to "capitalist economy as such." ${ }^{\prime 87}$ On the contrary, it was, Arendt argued, overaccumulation of capital within the nation-state that tempted the bourgeoisie to impose their economic interests on national political life. ${ }^{88}$ This led to the temporary dominance of the economic over the political in imperialism's early phases. This economic intrusion into the political had a corrupting influence, since "[o]nly the illimited [sic] accumulation of power could bring about the illimited accumulation of capital." 89 In distinctly Bonapartist language, Arendt argued that, meanwhile, "the refuse of all classes," understood as the peculiar product of a capitalist society, disciplined by racism and financed by the bourgeoisie themselves, became a menacing political force. $^{90}$ The political, then, soon ran out of control of the economic again, until "[o]nly a few elderly gentlemen in high finance still believe[d] in the inalienable rights of profit." ${ }^{\text {"1 }}$ The economic poisoned the political, and the political, in

\footnotetext{
${ }^{83}$ On this reading, one can clearly see the connections between Origins and The Human Condition. For more on this connection see Margaret Canovan, Hannah Arendt: A Reinterpretation of Her Political Thought (Cambridge, 1992); see also Caroline Ashcroft, "Jewishness and the Problem of Nationalism: A Genealogy of Arendt's Early Political Thought," Modern Intellectual History 14/2 (2017), 421-49.

${ }^{84}$ Arendt, Burden, 45-6. See also her claim (ibid., 79) that nineteenth-century antisemitism, "at any rate, reached its climax in France and was defeated because it remained a national domestic issue without contact with imperialist trends."

${ }^{85}$ The importance of "imperialism" to Arendt's thinking has been remarked by Jones in The Lost Debate, 204. Jones does not develop the point in the same direction as this article.

${ }^{86}$ Tsao, "Three Phases," 587.

${ }^{87}$ Ibid., 583.

${ }^{88}$ Hannah Arendt, "Expansion and the Philosophy of Power," Sewanee Review 54/4 (1946), 601-16, at 605.

${ }^{89}$ Ibid., 606.

${ }^{90}$ Hannah Arendt, "Imperialism: Road to Suicide," Commentary 1/4 (1946), 27-35, at 30, original emphasis.

${ }^{91}$ Ibid., 29.
} 
turn, poisoned the economic. What is perhaps most original and interesting about this argument is that it did not debate the supremacy or otherwise of political and economic, but rather retraced a dialectical relationship between the two. Nevertheless, the terms of the argument (including bourgeoisie, accumulation of capital, the Bonapartist trope of the "refuse of all classes," political versus economic spheres) and the framing role played by "imperialism" give good reason for reading Arendt's arguments as an intervention in the intra-Marxist debate outlined abovean intervention made in the languages of Marxism.

In Origins, too, Arendt was open about her debts to J. A. Hobson, Hilferding, Lenin and above all Rosa Luxemburg. ${ }^{92}$ One sees this in her thoroughly orthodox account of "the overproduction of capital and the emergence of 'superfluous' money, the result of oversaving, which no longer finds productive investment within the national borders." ${ }^{13}$ Likewise her account of the emergence of fascism as "The Alliance between the Mob and Capital" is very much of a piece with those Marxist accounts of fascism which traced precisely this link. ${ }^{94}$ Compare, for example, Arendt's account of how "the German bourgeoisie staked everything on the Hitler movement and aspired to rule with the help of the mob," which then ran out of control, with Bauer's account of how the fascist militia "became too strong for the bourgeoisie to use it as a simple tool." ${ }^{.95}$ Arendt, then, took these accounts seriously indeed as important theories of this element of totalitarianism, but wanted to drop some of the baggage. At times, her argument amounted to the Marxian move of turning the imperialism discourse on its head; in any case, the provenance and the interlocuters are clear: "Imperialism must be considered the first stage in the political rule of the bourgeoisie rather than the last stage of capitalism." ${ }^{\text {"T6 }}$ This is surely an allusion to Lenin's claim that imperialism was "the highest stage of capitalism" and Hilferding's that it was the "latest."

The centrality of social histories of racism and anti-Semitism to Arendt's treatment of imperialism and the crisis of the nation-state is often considered to be the distinguishing trait of her arguments about the topic that sets her apart from the Marxists. The long diversions into "high society's constantly growing admiration for the underworld" and the moral degeneration inflicted on the perpetrators of race-imperialism are indeed original in many points of detail. ${ }^{98}$ And yet, even here there are striking resemblances with the work of Luxemburg. In suggestive

\footnotetext{
${ }^{92}$ See esp. Arendt, Burden, 148 n. 45. For a more general treatment of Arendt's affinities with Luxemburg see Philip Spencer, "From Rosa Luxemburg to Hannah Arendt: Socialism, Barbarism and the Extermination Camps," European Legacy 11/5 (2006), 527-40.

${ }^{93}$ Arendt, Burden, 135. It is interesting to note, then, that Arendt's argument about "superfluity" was directly descended from Marxist political-economic thinking about unemployment and excess capital. This point is also made in Steven E. Aschheim, Scholem, Arendt, Klemperer: Intimate Chronicles in Dark Times (Indianapolis, 2001), 53.

${ }^{94}$ Arendt, Burden, 147-57.

${ }^{95}$ Ibid., 124; Bauer, Zwischen zwei Weltkriegen?, 123. Again this discourse was widespread and other examples could serve a similar purpose.

${ }^{96}$ Arendt, Burden, 138.

${ }^{97}$ The subtitle to Hilferding's Finanzkapital was "eine Studie über die jüngste Entwicklung des Kapitalismus."

${ }^{98}$ Arendt, Burden, 154-7; see also 185-90.
} 
if elliptical remarks, which are worth quoting in full, Luxemburg had argued in The Russian Revolution,

The Lumpenproletarian element is deeply embedded in bourgeois society ... Events in Germany-and more or less in other countries-have shown how easily all sections of bourgeois society are subject to such degeneration. The gradations between commercial profiteering, fictitious deals, adulteration of foodstuffs, cheating, official embezzlement, theft, burglary and robbery, flow into one another in such fashion that the boundary line between honorable citizenry and the penitentiary has disappeared. In this the same phenomenon is repeated as in the regular and rapid degeneration of bourgeois dignitaries when they are transplanted to alien social soil in an overseas colonial setting. With the stripping off of conventional barriers and props for morality and law, bourgeois society itself falls victim to direct and limitless degeneration, for its innermost law of life is the profoundest of immoralities, namely the exploitation of man by man. ${ }^{99}$

The translator notes that the term "degeneration" is Verlumpung in the German, so that the idea might plausibly be read as one of imperialism creating a morally degraded Lumpenbourgeoisie. It should also be noted that the whole essay was published posthumously and this passage in particular appeared as a footnote, having been found as a separate sheet of paper without a clear place in the manuscript. Finally, although Arendt cited Luxemburg's Accumulation of Capital, it is not clear whether she had read The Russian Revolution at the time of writing Origins. Nonetheless, the ideas in it are so remarkably similar to Arendt's own in Origins that the possibility of direct influence must be entertained. Furthermore, this connection also shows that Arendt's construction of "the mob"-described in familiar Bonapartist-theoretical terms as "déclassés," "the refuse of all classes" and "the scum of the big cities"100 - as the "by-product" of class society had a long tradition of Marxist analysis. ${ }^{101}$ Arendt did, of course, make original moves in this argument, as in her claim that the very belief in "class struggle" as a "universal ... characteristic of modern political life" itself spurred imperialism and the formation of a declassed mob. ${ }^{102}$ Nevertheless, if the argument is original and, indeed, subversive, it was made by playing on the languages of capitalist imperialism and Bonapartism in the Marxist tradition.

Arendt's second theory of totalitarianism, as presented especially in the argument of Part Three of Origins, was drawing on and responding to anticommunist Marxism too. ${ }^{103}$ As the analysis turns to "Totalitarianism in Power," the echoes become fainter, and the sources and themes are increasingly different. But the earlier chapters, on the

\footnotetext{
${ }^{99}$ Rosa Luxemburg, "The Russian Revolution," in Bertram D. Wolfe, ed., The Russian Revolution and Leninism or Marxism (Ann Arbor, 1961), 273-4.

${ }^{100}$ Arendt, Burden, 109, 155, 151.

${ }^{101}$ Ibid., 155.

${ }^{102}$ Ibid., 152.

${ }^{103}$ For the influence of ex-communists and Marxists on Arendt see Jones, The Lost Debate, 202; Michael Rohrwasser, "Totalitarismustheorie und Renegatenliteratur," in Alfons Söllner, Ralf Walkenhaus, and Karin Wieland, eds., Totalitarismus: eine Ideengeschichte des 20. Jahrhunderts (Berlin, 1997), 105-16; Karl Schlögel,
} 
rise of totalitarianism and its party movement, show much clearer links. Granted, in the first chapter of this section, Arendt explicitly ruled out the interpretation of Hitler as a proxy for monopoly capitalism-but so did Borkenau and Burnham. ${ }^{104}$ And yet the very chapter title- "A Classless Society" - is obviously a pun on the idea of communism as a classless society free of oppression and hardship-the dark irony, for Arendt, was that capitalism did indeed issue in the classless society, but that such a society was a nightmare rather than an idyll.

In addition, the primary argument of this chapter drew heavily on Borkenau's version of totalitarianism-as-Bonapartism, in the sense of having its social base in a declassed mob. Of course, Arendt's argument about "the breakdown of class society" and the rise of the masses brought together multiple sources, including Gustave Le Bon, but the engagement with Borkenau was considerably more sustained. ${ }^{105}$ In an argument in which she cited Borkenau's claim for the "mass" basis of Nazism and Communism, Arendt wrote in similar terms to those of Borkenau. So, for Arendt: "Masses are not held together by a consciousness of common interest and they lack that specific class articulateness which is expressed in determined, limited, and obtainable goals." ${ }^{106}$ Compare this with Borkenau's claim that Continental, class-based democracy, "with all its drawbacks, had its value in that it set people well-defined and intelligible tasks." ${ }^{107}$ Indeed, the general structure of Arendt's story and its themes appears to owe a great deal to the anticommunist Marxist elegy for the age of free trade and its indictment of the breakdown of democratic party politics in the classless deadlock that followed. ${ }^{108}$

In sum, then: throughout the first two versions of Arendt's totalitarianism theory, she shared with interwar Marxism a story of liberal democracy's collapse in the face of a deadly crisis of capitalist civilization, a crisis underpinned by imperialism abroad and its consequences at home. Like the Marxists, Arendt ran this alongside an arguably Bonapartist story of social decomposition in the metropole, in particular the danger of declassed mobs in alliance with the bourgeoisie. And the terrain on which this material was debated in Marxist circles-the nature of the political and the economic spheres-was likewise her terrain.

\footnotetext{
"Archäologie totaler Herrschaft: Russland im Horizont Hannah Arendts," in Gerd Koenen and Lew Kopelew, eds., Deutschland und die Russische Revolution, 1917-1924 (Munich, 1998), 790-804, at 792-4.

${ }^{104}$ Arendt, Burden, 301.

${ }^{105}$ Ibid., quote at e.g. 306; Lebon [sic] at 310 n. 15a; Borkenau at 301 n. 3, 304 n. 11, 305 n. 12, 323 n. 56. Indeed, that Le Bon's footnote was $15 \mathrm{a}$, rather than simply 15 or 16 , is presumably because it was inserted late and would otherwise have interfered with the typesetting.

${ }^{106}$ Arendt, Burden, 305; Cf. Borkenau, The Totalitarian Enemy, where terms such "classless" and "déclassé" abound: e.g. 164, 212.

${ }^{107}$ Borkenau, The Totalitarian Enemy, 164, 165.

${ }^{108}$ There are notable similarities between Borkenau's celebration of British parliamentary democracy for living up to the nineteenth-century ideal that parties "were supposed to stand for principles, not for interests," and Arendt's portrait of the "Anglo-Saxon party ... founded on some 'particular principle' for the service of the 'national interest." See respectively Borkenau, The Totalitarian Enemy, 155; and Arendt, Origins, 254. Pursuing this connection would be beyond the scope of this article, and might point to an alternative-but not mutually exclusive-genealogy of discourses around "Continental democracy."
} 


\section{Conclusion: towards the classical theory of totalitarianism}

Arendt's third theory of totalitarianism-the last to appear as part of Origins, though arguably Eichmann in Jerusalem offered further revisions-was written in different political-theoretical languages. The most substantial revision between the first and second editions of Origins was the addition of a new chapter, itself based on an article published in 1953. Both chapter and article were entitled "Ideology and Terror: A Novel Form of Government." 109 It was at this point that Arendt made her argument for understanding totalitarianism as distinct from tyranny. For Arendt, it was not that totalitarian regimes recognized no law; rather, they answered to higher, ideological laws of history or nature. For those ruled in this way, the law was just as unpredictable as, and yet more oppressive than, the lawlessness of personal despotism. This was what made totalitarianism essentially novel. As she put it, "Totalitarian lawfulness, defying legality and pretending to establish the direct reign of justice on earth, executes the law of History or of Nature without translating it into standards of right and wrong for individual behaviour," and thus "all laws have become laws of movement." ${ }^{110}$ Since human spontaneity will never conform to such crude laws, Arendt argued, ever more terror is required to bring life into line with these ideological strictures. Granted, Arendt's use of "law of movement" has its own Hegelian ring, but this particular focus on ideology as the source of terror cannot be fitted into the Marxist genealogy traced here. The idea of totalitarianism's radical novelty as such was not new, not even in Arendt's own work. ${ }^{111}$ But this conception of "a novel form of government," whose conformity to ideological laws of movement locked it into a cycle of escalating, arbitrary terror, was a genuinely new contribution, and its roots are hard to trace in the earlier edition of Origins.

The phrase "a novel form of government" has an interesting history of its own which speaks to the contested relationship between Arendt's Origins and Friedrich and Brzezinski's Totalitarian Dictatorship and Autocracy. Although some sources concede an affinity, ${ }^{112}$ there is a widespread sense of "a sparseness of mutual citation" between the texts and, as indicated above, of Arendt's masterpiece operating at another level. ${ }^{113}$ A close reading of both shows a great deal of agreement and mutual respect. Up to 1953, Friedrich referred to totalitarianism as "sui generis" or "historically unique." ${ }^{\prime 14}$ But during the discussion of Friedrich's paper at a

\footnotetext{
${ }^{109}$ Hannah Arendt, "Ideology and Terror: A Novel Form of Government," Review of Politics 15/3 (July 1953), 303-27. Cf. the last chapter of Arendt, Origins.

${ }^{110}$ Arendt, "Ideology and Terror," 307, 308, original emphasis.

${ }^{111}$ See e.g. Carlton J. H. Hayes, "The Novelty of Totalitarianism in the History of Western Civilization," Proceedings of the American Philosophical Society 82/1 (1940), 91-102. Totalitarianism's novelty was the context for Arendt's remark on its unprecedented "absolute evil." Arendt, Burden, ix.

${ }^{112}$ E.g. Klaus Hildebrand, "Stufen der Totalitarismus-Forschung," Politische Vierteljahresschrift 9/3 (1968), 397-422, at 405-6; Wippermann, Totalitarismustheorien, 4.

${ }^{113}$ Alfons Söllner, "Hannah Arendt's The Origins of Totalitarianism in Its Original Context," European Journal of Political Theory 3/2 (2004), 219-38, at 222; see also Samuel Moyn, "Modernity and the Specter of Totalitarianism," in Gordon and Breckman, The Cambridge History of Modern European Thought, vol. 2, $417-37$.

${ }^{114}$ See e.g. Carl J. Friedrich, "Military Government and Dictatorship," Annals of the American Academy of Political and Social Science 267/1 (1950), 1-7, at 1; Carl J. Friedrich, "The Unique Character of Totalitarian Society," in Friedrich, ed., Totalitarianism: Proceedings of a Conference Held at the American Academy of Arts and Sciences, March 1953 (Cambridge, MA, 1954), 47-60, at 47.
} 
1953 conference on "Totalitarianism," Arendt-as well as signaling her "agreement with almost all of Mr. Friedrich's statements"- suggested that he substitute these phrases for her own: Friedrich's thesis "can only mean that totalitarian domination constitutes a novel form of government." ${ }^{115}$ In Totalitarian Dictatorship and Autocracy, Friedrich and Brzezinski accepted Arendt's recommendation, and the phrase "a novel form of government" took pride of place in the preface to this book, with the similar phrase "a novel kind of government" used in the introduction. ${ }^{116}$ This encounter was not fleeting-three years later, in 1956, Arendt presented a paper at Friedrich's conference on "Authority." "17 But more significantly, their sharing the phrase was not a superficial resemblance; rather, it represented a shared conception of totalitarianism's defining features. Arendt, indeed, was one of the few authors accorded real respect by Friedrich and Brzezinski, and particularly so on the question of ideology. Their argument that totalitarianism "considers all ordinary laws merely as expressions of laws of nature and history," and that its laws were "treated merely as the emanation of such laws of movement," could have been lifted from Arendt's work, which, indeed, was cited on this point. ${ }^{118}$ Agreement on the constitutive role of ideology in untamable terror as the essence of totalitarianism could reasonably be said to unite a variety of contributions to a specific moment of "classical totalitarianism theory." 119

What is the significance of the genealogy traced in this article? First, it clarifies what exactly was "lost in translation" as the languages of interwar Marxism were deployed in new contexts or spoken with radically different accents. For William David Jones, what was worth recovering from The Lost Debate was simply that there was a tradition of antitotalitarian socialism. ${ }^{120}$ But one gets less of a sense of what the shared perspectives of this tradition were and what set it apart from subsequent theories of totalitarianism. Reading some of the earliest theories of totalitarianism in terms of the Marxist languages of imperialism and Bonapartism has highlighted that a particular concern with the fusion of political and economic power, resting on shared historical narratives about the failure of interwar democracy, gave a degree of unity and coherence to the anticommunist Marxist moment of totalitarianism theory. The suggestion of a neo-feudal fusion also provoked responses from more "orthodox" perspectives like that of Franz

\footnotetext{
${ }^{115}$ See Hannah Arendt's contribution to the "Discussion" of Friedrich, "The Unique Character of Totalitarian Society," in Friedrich, Totalitarianism: Proceedings, 74-84, at 75-6.

${ }^{116}$ Friedrich and Brzezinski, TDA, vi, 3. Lietzmann also notes the phrase "a novel form of government" in Friedrich's work, and identifies this as the defining feature of what he calls "classical totalitarianism theory." But he does not notice that Arendt, too, used the phrase and indeed explicitly ruled her out of "classical theory." See Hans J. Lietzmann, "Von der konstitutionellen zur totalitären Diktatur: Carl Joachim Friedrichs Totalitarismustheorie," in Söllner, Walkenhaus and Wieland, Totalitarismus: Eine Ideengeschichte, 174-92.

${ }^{117}$ Carl J. Friedrich, ed., Authority (Cambridge, MA, 1958).

${ }^{118}$ Friedrich and Brzezinski, TDA, 5.

${ }^{119}$ See also perhaps Raymond Aron, Democracy and Totalitarianism: A Theory of Political Systems, ed. Roy Pierce (Ann Arbor, 1990), esp. 178-191 on "Ideology and Terror." Wippermann also uses the phrase "classical theories" to describe Arendt and Friedrich's work, but not with the same argument as this article. See Wippermann, Totalitarismustheorien, 4.

${ }^{120}$ Jones, The Lost Debate, 173-5.
} 
Neumann. This language of political and economic spheres can be contrasted with the more common public-versus-private framing that typically underpinned the classical theories of totalitarianism in the Cold War. ${ }^{121}$ Similarly, Arendt's place in this history becomes a lot clearer. Much of her thinking-for example about the dangers of classlessness for democracy; the role of imperialism as a politically, economically and even culturally corrosive force; and the interaction between these two elements as a cause of fascism and totalitarianism-drew on and developed these Marxist languages of imperialism and Bonapartism. On the other hand, the relative discontinuity of the "Ideology and Terror" essay can be seen and analyzed more clearly in light of the same discussion.

Second, the genealogy suggests a different perspective on "Cold War" thought as such. It was plausibly, and perhaps paradoxically, the subject of totalitarianism itself that prompted a thinker like Friedrich to engage with the literature of Marxism. Friedrich had not significantly engaged with Marxist thought in the 1930s, in texts such as Constitutional Government and Politics, or even in his earliest work on totalitarianism. ${ }^{122}$ This appears to have changed when he took up work in earnest on a book-length treatment of the topic. In his paper at the aforementioned "Totalitarianism" conference in 1953, he framed his work as a scholarly synthesis, writing, "A detailed inspection of the available evidence would seem to suggest that everyone [sic] of the factors which has been stressed as offering by itself an explanation of the origin of totalitarianism has played its role," which included "the economic crisis and the 'contradictions' of an aging capitalism." ${ }^{23}$ Although at times criticizing it sharply, Friedrich and Brzezinski also engaged substantially with Neumann's Behemoth - which was the most cited single text in Totalitarian Dictatorship and Autocracy-and, ironically, used anticommunist Marxists like Burnham as their main source of counterpoints to Neumann. ${ }^{124}$ This is not to say that the book was itself written in Marxist languages, but it does point to the difficulties inherent in trying to erect any ideological cordon sanitaire between "left-wing" or "right-wing" theories of totalitarianism.

In sum, then, Origins emerges as an ambiguous and even contradictory achievement: a remarkable contribution to both the Marxist and the Cold War traditions of totalitarianism theory-perhaps even a bridge of sorts between them. Totalitarianism as "a novel form of government" no doubt had its own sources, and warrants its own genealogy, one that would complement rather than contradict the one offered here. But as a theorist of imperialism, and indeed of the political, Arendt owed a great deal to Marxism, one of the twentieth century's most important spaces of argument.

Acknowledgements. Many thanks to all attendees at the European University Institute's 2020 Graduate Conference in Intellectual History and at the Political Thought and Intellectual History Graduate

\footnotetext{
${ }^{121}$ Sophie Joscelyne, "Norman Mailer and American Totalitarianism in the 1960s," Modern Intellectual History, Online first (2020), at 6-7, https://doi.org/10.1017/\$1479244320000323.

${ }^{122}$ Carl Joachim Friedrich, Constitutional Government and Politics (New York and London, 1937); C. J. Friedrich, "Greek Political Heritage and Totalitarianism," Review of Politics 2/2 (1940), 218-25; Friedrich, "Military Government and Dictatorship."

${ }^{123}$ Friedrich, "The Unique Character of Totalitarian Society," 48-9.

${ }^{124}$ Friedrich and Brzezinski, TDA, e.g. 210.
} 
Workshop at the University of Cambridge for their feedback on versions of this article. Particular thanks are due to Emily Evans and Christopher Brooke, as well as three anonymous reviewers at Modern Intellectual History for comments that resulted in a much-improved article. The research was carried out on an Arts and Humanities Research Council Studentship.

Cite this article: Devlin N (2023). Hannah Arendt and Marxist Theories of Totalitarianism. Modern Intellectual History 20, 247-269. https://doi.org/10.1017/S1479244321000603 